\title{
PENGARUH PERSEPSI DAN PREFERENSI KONSUMEN TERHADAP KEPUTUSAN PEMBELIAN MAKANAN SIAP SAJI FRIED CHICKEN PADA D'BESTO DI KOTA PADANG CABANG SITEBA
}

\author{
Aldri Dolly Fernando, Riri Mayliza \\ Sekolah Tinggi Ilmu Ekonomi KBP \\ dolifernando86@gmail.com \\ ririmayliza@akbpstie.ac.id
}

\begin{abstract}
The purpose of this study was to determine the effect of consumer perceptions and preferences on the purchase decision of fried chicken fast food on d'besto in the Siteba branch city of Padang. The variables in this study are Perception (X1), Consumer Preference (X2) and Purchase Decision (Y). The sample used was 92 people, the sampling technique used was purposive sampling method. Data collection used a questionnaire, while data analysis techniques were performed using multiple linear regression analysis. The results showed that the perception variables had a positive and significant effect $(0.037<0.05)$ on purchasing decisions. Consumer preference variables have a positive and significant effect $(0.000<0.05)$ on purchasing decisions. It is expected that the next researcher will be able to use research as a reference which will provide a comparison in conducting further research and useful for d'besto.
\end{abstract}

Keywords: Perception, Consumer Preference, Purchase Decision

\section{PENDAHULUAN}

Keberhasilan setiap negara menjalankan roda pemerintahan akan membawa masyarakat ke pintu kejayaan dan kemakmuran. Demi menjaga kestabilan perekonomian negara, pemerintah bekerja

keras menjaganya melalui kebijakan yang bersifat efektif dan cepat dengan mengurangi pengeluaran negara. Indonesia sasat sekarang ini mengalami kemajuan dan berada pada kondisi stabil. Semakin berkembangnya jumlah industri, rivalitas industri juga akan kian tajam. Maka setiap perusahaan di indonesia perlu selalu berusaha meningkatkan efisiensinya. Bertambah tinggi efisiensi akan bertambah besar kemampuan perusahaan modal yang dikeluarkan dan laba perusahaan itu sendiri. Perusahaan harus mampu berkompetensi dan mempertahankan bisnisnya dalam kondisi bisnis yang berat. Dengan perkembangan teknologi, pesaing baru, hukum dan peraturan pemerintah yang selalu berubah - ubah diharapkan nantinya perusahaan bisa bertahan dan terus bersaing untuk memenuhi keinginan dan harapan konsumen. Secara signifikan aktifitas manusia pada masa sekarang mengalami peningkatan. Diantaranya 
adalah industri makanan yang menjadi pokok kebutuhan manusia untuk memenuhi segala aktifitasnya. Industri makanan mengalami pertumbuhan yang sangat pesat sesuai kebutuhan dan gaya hidup manusia.

Gaya hidup manusia sekarang menginginkan semuanya yang praktis dan simpel. Dimana semua perusahaan berlomba - lomba untuk memnjakan konsumennya dengan fasilitas pelayanan yang membuat konsumen merasa nyaman. Gaya hidup semacam itu tidak saja dinikmati untuk konsumen kelas atas, melainkan konsumen kelas menengah dan konsumen kelas bawah yang tinggal di desa. Dimana konsumen yang berada atau tinggal di perdesaan meniru gaya orang yang tinggal di kota dengan memakan mkanan cepat saji. Restoran cepat saji atau fast food mulai terkenal di indonesia pada awal tahun 1980, salah satunya adalah fried chicken.

Fried chicken berasal dari bahasa inggris yaitu kata fried yang berarti gorengan dan chicken yang artinya ayam. Fried chicken adalah ayam goreng tepung yang dikenalkan oleh budaya asing. Fried chicken atau ayam goreng memang sudah menjadi menu primadona masyarakat indonesia. Penggemarnya, mulai dari anak- anak sampai orang tua, masyarakat ekonomi menengah bawah sampai kelas atas. Makanan cepat saji berkembang dengan merek internasional, seperti KFC, MCD, CFC, Wendy's DLL maupun domestic seperti RFD, quick chicken, d'Besto, Rocket chicken DLL yang tumbuh subur di negara indoseia. Termasuk ayam goreng berupa gerobak yang berkembang hingga ke perumahan. D’Besto misalnya. Berdiri pada bulan maret 1994, restoran siap saji ini menawarkan produk unggulan lain seperti burger dan spaghetti, di samping produk pelengkap seperti french fries, dan bermacam minuman dengan konsep kuliner fried chicken \& burger yang lezat, bersih, higienis, sehat, halal, cepat dam mudah dengan pelayanan dan keramahtamahan khas indonesia.

D'Besto chicken \& burrger didirikan oleh dua orang dari alumni fakultas kedokteran hewan IPB, Drh. Setyajid dan Drh. Evalinda untuk pertama kali membuka usaha kecil ayam goreng krispi dengan tema kaki lima yang diberi nama Kentuku fried chicken, atau lebih dikenal sebagai KUFC. Selaku penyedia makanan siap sajii masyarakat kelas bawah, KUFC ternyata mendapat respon positif dari masyarakat bahkan menjadi pionir dalam usaha fried chicken krispi kaki lima sehingga membuka cabang di luar kota, seperti Bandung, Bali, Yogyakarta, Padang dan Mataram. KUFC mengalami pasang surut pada saat krisis moneter nasional-internasional di tahun 1998, juga ketika beberapa kali terjadi wabah flu burung. Beberapa cabang di luar kota hanya menyisakan sedikit gerai saja di wilayah Bogor dan Depok selebihnya ditutup.

Tahun 2010 KUFC kembali muncul dengan terobosan baru dan meluncurkan merek baru bernama d'Besto yang lebih membidik pasar di kalangan menengah. Dengan penyesuaian potongan, harga yang tepat dan kualitas rasa, serta tampilan konsep mini resto yang menarik. Tampilan yang eye catching brands dan khas d'Besto muncul menjadi nama yang patut diperhitungkan dalampersaingan bisnis kuliner diwilayah Jabodetabek.

Permasalahan yang sering muncul di dalam pemasaran D'Besto yaitu masalah pelayanan yang dinilai masih kurang memuaskan pelanggan, dilihat dari masih adanya pelanggan yang berkomentar dan menyampaikan keluhannya pada 
pihak D'Besto. Hal ini menyebabkan penurunan omset tiap bulannya pada D'Besto. Selain itu banyaknya bermunculan restoran makanan cepat saji fried chicken di Padang seperti KFC, McD, CFC, O'Chicken, Texas, SS Fried Chicken dan sebagainya yang siap bersaing di pasar membuat persaingan yang begitu ketat. KFC dan Mcd misalnya, kedua restoran cepat saji ini sudah dulu memasuki pasar di indonesia termasuk di Padang dan sudah mendapatkan tempat di hati konsumen serta mendapatkan tanggapan positif. Karena selain rasanya yang khas dari masing - masing restoran, mutu produk dan pelayanan juga sangat di jaga. Dengan makanan yang enak dan bertaraf internasional kedua restoran ini menjadi tempat yang paling banyak di buru oleh konsumen terutama konsumen kelas menengah ke atas. Kedua restoran ini merupakan pesaing yang paling kuat bagi D'Besto. Beda hal nya dengan KFC dan McD, D'Besto lebih di untungkan dengan pangsa pasarnya karena membidik pasar kalangan menengah. Itu artinya D'Besto bisa terjangkau oleh semua kalangan dengan harga lebih murah namun rasa dan kualitas tidak kalah dengan Fried Chicken waralaba internasional. Pengambilan keputusan konsumen merupakan aspek utama buat pemasar untuk menentukan apakah konsumen bakal mengambil keputusan pembelian atau tidak atas keputusan yang ditetapkan. Wardhani (2013), Keputusan pembelian berhubungan erat dengan informasi yang dimiliki konsumen dan bermacam faktor yang dipengaruhi oleh wawasan konsumen terhadap produk yang akan dibelinya. Pada proses pengambilan keputusan konsumen, pengaruh situasi konsumen akan memberikan hasil akhir yang berbeda untuk masing-masing konsumen. Tahapan mencari informasi dipengaruhi juga oleh tingkat konsumen butuhkan pada produk yang dicarinya. Keputusan konsumen dipengaruhi oleh faktorliingkungan eksterrnal seperti faktor budaya, social, pribadi,dan psikologis

Persepsi di definisikan sebagai prosses individu dalam memilih, mengorganisassikan, menafsirkan masukan dan informasi untuk menciptakan sebuah gambaran yang bermakna tentang dunia (Wardhani 2013).

Basril (2008), mendefinisikan persepsi sebagai proses dimana seorang individu memilih, mengorganisasikan dan mengintepretasikan stimuli ke dalam gambaran yang mempunyai makna dan masuk akal sehingga dapat dimengerti. Persepsi meliputi semua proses yang dilakukan seseorang dalam memahami informasi mengenai lingkungannya, sehingga proses pemahaman ini akan mempengaruhi seseorang mengorganisasikan persepsinya.

\section{KAJIAN LITERATUR \\ Keputusan Pembelian}

Menurut Wardhani (2013), keputusan pembelian konsumen merupakan titik suatu pembelian dari proses evaluasi. Hariadi (2013), keputusan pembelian merupakan proses pengintegrasian yang dikombinasikan untuk mengevaluasi dua atau lebih perilaku alternatif dan memilih salah satu di antaranya. Menurut Basril (2008), ada lima tahapan proses keputusan pembelian, yaitu :

1. Pengenalan Kebutuhan (Need Recognition)

Kesadaran konsumen akan suatu masalah atau kebutuhan yang ditentukan oleh rangsanngan internal dan eksternal. 
2. Pencarian Informasi (Information Search)

Ketertarikan konsumen mungkin mencari lebih banyak informasi atau mungkin tidak.

3. Evaluasi Alternatif (Alternative Evaluation)

Dengan pilihan merk yang sudah ada diharapkan konsumen bisa mengevaluasinya dan membuat keputusan dengan tepat.

4. Keputusan Pembelian (Purchase Decission)

Konsumen membeli merek yang paling disukai yang dipengaruhi oleh dua faktor. Pertama, perilaku dan sifat orang lain, ada orang yang mempengaruhi konsumen. Kedua, kondisi yang bukan diharapkan, maksudnya keputusan pembelian bisa saja berubah dengan hal - hal yang tidak terduga.

5. Perilaku Pascapembelian (Postpurchase Behavior)

Perbandingkan antara harapan atau ekspektasi konsumen akan produk dengan kinerja dari produk.

Menurut Wardhani (2013), ada empat indikator keputusan pembelian, yaitu :

1. Kemantapan atas suatu produk.

2. Kebiasaan pada pembelian produk.

3. Memberikan rekomendasi pada orang lain.

4. Melaksanakan pembelian ulang.

Menurut Azizah (2008), pembelian konsumen dipengaruhi beberapa faktor sebagai berikut : Faktor Budaya, Faktor Sosial, Faktor Pribadi, Faktor Psikologi

Persepsi

Menurut Adiningsih (2012), persepsi adalah proses yang menyangkut masuknya pesan atau informasi kedalam otak manusia, dengan adanya persepsi manusia selalu berhubungan dengan lingkungan sekitarnya.

Astuti (2013), mengatakan persepsi ialah proses yang dipakai individu untuk memilih, mengorganisasi, dan menginternpretasi masukan informasi untuk menciptakan gambaran dunia yang memiliki arti.

Menurut Wardhani (2013), ada beberapa indikator terjadinya persepsi, yaitu :

1) Ada objek yang akan dipersepsikan

2) Ada perhatian

3) Adanya alat indera atau receptor

Menurut Azizah (2008), Faktor yang mempengaruhi persepsi yaitu : Sikap, Motivasi, Minat, Pengalaman masa lampau, Harapan, Sasaran, dan Situasi. Preferensi

Menurut Basril (2008), mendefinisikan Preferensi konsumen diartikan sebagai kesukaan, pilihan atau sesuatu hal yang lebih disukai konsumen yang terbentuk dari persepsi konsumen terhadap produk.

Anggasari (2013), Preferensi konsumen berarti kesukaan, pilihan atau sesuatu yang lebih disukai oleh konsumen yang bisa terbentuk dari pemahaman dan ingatan konsumen melalui persepsi produk. 
Menurut Wardhani (2013), ada beberapa indikator yang digunakan dalam mengukur preferensi, yaitu:
a. Faktor sosial
b. Metode pembayaran
c. Pengaruh lingkungan

Menurut Azizah (2008), terdapat beberapa faktor yang mempengaruhi preferensi konsumen yaitu : Atribut, Kepentingan, Kepercayaan, dan Kepuasan.

\section{METODE PENELITIAN}

\section{Populasi dan Sampel}

Menurut Sugiyono (2015), Populasi merupakan wilayah generalisasi yang terdiri atas subyek atau objek yang mempunyai kuantitas dan karakteristiik tertentu yang ditetapkan oleh peneliti guna dipelajari dan kemudian ditarik kesimpulanya. Di dalam penelitian ini yang menjadi populasi adalah keseluruhan konsumen yang berkunjung pada d'besto cabang siteba Di kota Padang. Pada penelitian ini memiliki populasi sebesar 1200 orang. Sampel merupakan bagian dari jumlah yang dimiliki populasi, untuk itu sampel yang diambil harus betul betul mewakili (Sugiyono 2015). Dalam penelitian ini jumlah sampel yang digunakan sebanyak 92 orang di dapat ddengan menggunakan rumus Slovin sebagai berikut:

$$
\mathrm{n}=\frac{\mathrm{N}}{1+\mathrm{N}(\mathrm{e})^{2}}
$$

Keterangan :

$\mathrm{n}=$ Jumlah Sampel

$\mathrm{N}=$ Jumlah Total Populasi

$\mathrm{e}=$ Batas Toleransi Error

Pembahasan :

Diketahui : $\mathrm{N}=1200$ orang

Ditanya $: \mathrm{n}=$ ?

$$
\mathrm{e}=10 \%(0,1)
$$

Jawab :

$\mathrm{n}=\mathrm{N} /\left(1+\mathrm{N} .(\mathrm{e})^{2}\right)$

$\mathrm{n}=1200 /\left(1+1200 .(10 \%)^{2}\right)$

$\mathrm{n}=1200 /\left(1+1200 .(0.1)^{2}\right)$

$\mathrm{n}=1200 /(1+1200 .(0.01))$

$\mathrm{n}=1200 /(1+12)$

$\mathrm{n}=1200 / 13$

$\mathrm{n}=92,30$ dibulatkan menjadi 92 orang

\section{Devenisi dan Operasional Variabel}

Dalam penelitian ini terdapat dua jenis variabel yaitu variabel bebas dan terikat. Adapun yang berperan sebagai variabel bebas adalah persepsi dan preferensi konsumen, keputusan pembelian sebagai variabel terikat. 


\section{Teknik Pengumpulan Data}

Pengukuran data dalam penelitian ini adalah angket atau kuisioner daftar pernyataan yang disusun berdasarkan kisi-kisi dalam bentuk skala likert (skala lima tingkat). Skala likert ( likert scale ) didesain untuk menalaah seberapa kuat subjek setuja atau tidak setuju dengan pertanyaan 5 titik dengan susunan sebagai berikut (Sugiyono, 2015), ( 2, sedikit setuju $=3$, setuju $=4$, sangat setuju $=5$ ).

\section{Teknik Analisis Data}

Teknik analisis data yang digunakan adalah uji deskriptif uji validitas dan reabilitas, uji asumsi klasik dan analisis regresi linear

\section{Hasil dan Pembahasan}

Jumlah kuesioner yang diedarkan kepada responden sebanyak 92 eksamplar, seluruh kuesioner kembali seutuhnya karena penyebaran kuesioner dengan cara memberikan secara langsung dan ditunggu hingga selesai.

Responden adalah perempuan (54.3\%) dan laki - laki (45,7\%).

\section{Uji Validitas dan Reabelitas}

Menurut Sugiyono (2003:125) pengujian validitas adalah sebuah uji yang ditujukan untuk mengukur kebenaran dari apa yang sebenarnya diukur. Di dalam melakukan pengujian validitas peneliti menggunakan model corrected item - total corelaion, masaing-masing peryataan dinyatakan valid bila menghasilkan corrected item - total corelaion diatas atau sama dengan 0.30. Butir pertanyaan yang dinyatakan tidak valid akan dikeluarkan atau tidak digunakan mengukur sebuah variabel penelitian, dan variabel dikatakan andal (realiabel). Bila memiliki nilai cronbach's alpa minimal 0,60 (Sugiyono, 2015).

\section{Tabel 1.}

Uji Validitas dan Realibiltas

\begin{tabular}{|l|c|c|c|c|c|}
\hline \multicolumn{1}{|c|}{ Variabel } & $\begin{array}{c}\text { Jumlah } \\
\text { Butir } \\
\text { Pertanyaan }\end{array}$ & $\begin{array}{c}\text { Butir } \\
\text { Tidak } \\
\text { Valid }\end{array}$ & $\begin{array}{c}\text { Butir } \\
\text { Valid }\end{array}$ & $\begin{array}{c}\text { Cronbach's } \\
\text { alpa }\end{array}$ & Ket \\
\hline $\begin{array}{l}\text { Keputusan } \\
\text { Pembelian }\end{array}$ & 5 & - & 5 & 0,900 & Reliable \\
\hline Persepsi & 4 & - & 4 & 0,861 & Reliable \\
\hline $\begin{array}{l}\text { Preferensi } \\
\text { Konsumen }\end{array}$ & 8 & - & 8 & 0,873 & Reliable \\
\hline
\end{tabular}

Sumber: Data Olahan 2018

\section{Uji Asumsi Klasik}

Uji asumsi klasik yang digunakan yang digunakan pada penelitian ini adalah, uji normalitas, heteroskedastisitas dan multikoleniaritas.

\section{Uji Normalitas}

Uji normalitas adalah pengujian untuk mengkaji kenormalan variabel yang diteleti apakah data tersebut berdistribusi normal atau tidak (Sugiyono 2015). Dapat disimpulkan bahwa uji normalitas untuk melihat tingkat kenormalan variabel yang diteliti. Indikator yang digunakan Uji kolmogrov-smirnov dengan pedoman yaitu :

a. Jika nilai signifikansi $>0,05$, maka berdistribusi normal

b. Jika nilai signifikansi $<0,05$, maka tidak berdistribusi normal 


\section{Uji Multikolinearitas}

Uji multikolinearitas bertujuan untuk menguji apakah bentuk regresi ditemukan adanya korelasi antar variabel bebas (Ghozali 2011). Indikator uji multikonearritas yaitu apabila nilai tolerance $>0,1$, dan Variance Inflation Factor $(\mathrm{VIF})<10$ maka tidak terjadi gejala multikonearitas sehingga tidak adanya pengaruh antara variable yang satu dengan variable yang lainnya.

\section{Uji Heteroskedastisitas}

\section{Uji glejser}

Uji yang dipakai untuk mengetahui ada atau tidaknya masalah hetereoskedatisitas, yaitu : Uji Glejser. Dengan ketentuan jika nilai signifikasinya $>0,05$ dapat dikatakan model regresi tidak terjadi masalah heteroskedastisitas.

\section{Analisis Regresi Linear Berganda}

Tujuan menggunakan analisis regresi linear berganda dalam penelitian ini adalah untuk mengetahui pengaruh persepsi (X1) dan preferensi konsumen (X2) terhadap keputusan pembelian makanan siap saji fried chicken d'besto cabang siteba (Y). Hasil dari analisis regresi linear berganda yang diolah dengan SPSS, dapat diringkas pada Tabel, sebagai berikut:

Tabel 2.

Hasil Uji Regresi Linear Berganda

\begin{tabular}{|c|l|c|c|c|}
\hline Variabel Terikat & $\begin{array}{c}\text { Konstanta dan } \\
\text { Variabel Bebas }\end{array}$ & $\begin{array}{c}\text { Koefisien } \\
\text { Regresi }\end{array}$ & Signifikan & Keterangan \\
\hline $\begin{array}{c}\text { Keputusan } \\
\text { Pembelian Fried } \\
\text { Chicken d'Besto } \\
\text { (Y) }\end{array}$ & Konstanta (a) & 1,057 & 0,001 & \\
\cline { 2 - 5 } & $\begin{array}{l}\text { Persepsi } \\
\text { Konsumen }\end{array}$ & 0,254 & 0,037 & H1 Diterima \\
\cline { 2 - 5 } & $\begin{array}{l}\text { Preferensi } \\
\text { Konsumen }\end{array}$ & 0,485 & 0,000 & H2 Diterima \\
\hline
\end{tabular}

Sumber : Data Olahan 2018

Berdasarkan hasil analisis regresi linear berganda diatas, diperoleh persamaan regresi linear berganda:

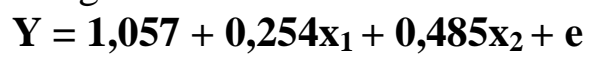

Hasil analisis regresi lineaar berganda dapat diintrepretasikan bahwa variabel persepsi dan preferensi konsumen berpengaruh positif dan signifikan terhadap keputusan pembelian makanan siap saji fried chicken d'besto karena memiliki nilai signifikan lebih kecil dari $\alpha=0,05$.

\section{PEMBAHASAN}

Pengaruh Persepsi Konsumen Terhadap Keputusan pembelian Pada D'besto di Kota Padang

Berdasarkan hasil pengujian hipotesis pertama, ditemukan bahwa variabel persepsi berpengaruh positif dan signifikan terhadap keputusan pembelian pada D'besto di Kota Padang. Berdasarkan hasil uji t pada variabel persepsi nilai signifikansiyang diperoleh sebesar 0,037 yang lebih kecil dari 0,05. Hal ini dapat diartikan bahwa variabel persepsi berpengaruh positif dan signifikan terhadap keputusan pembelian, dengan demikian, hipotesis pertama (H1) dalam penelitian ini yang menyatakan bahwa persepsi berpengaruh 
signifikan terhadap keputusan pembelian pada D'besto di Kota Padang, dinyatakan diterima.

Hal ini bermakna tingkat keputusan pembelian akan akan memberikan pengaruh yang signifikan terhadap keputusan pembelian D'besto di Kota Padang, hal ini selaras dengan penelitian yang dilakukan oleh Widya Wardani (2015) tentang Pengaruh Persepsi dan Preferensi Konsumen Terhadap Keputusan Pembelian Hunian Green Products, menemukan bahwa persepsi dan preferensi berpengaruh signifikan terhadap keputusan pembelian. Sesuai dengan penelitian yang dilakukan oleh Immarotul Azizah (2008), tentang Analisis Pengaruh Persepsi dan Preferensi Konsumen terhadap Keputusan Pembelian, menemukan bahwa persepsi dan preferensi berpengaruh signifikan terhadap keputusan pembelian.

\section{Pengaruh Preferensi Konsumen Terhadap Keputusan pembelian Pada D’besto di Kota Padang}

Berdasarkan hasil pengujian hipotesis kedua, ditemukan bahwa variabel preferensi berpengaruh positif dan signifikan terhadap keputusan pembelian pada D'besto di Kota Padang. Berdasarkan hasil uji t variabel preferensi memiliki nilai signifikan sebesar 0,000 yang lebih kecil dari 0,05. Hal ini dapat diartikan bahwa variabel preferensi berpengaruh positif dan signifikan terhadap keputusan pembelian, dengan demikian, hipotesis kedua $(\mathrm{H} 2)$ dalam penelitian ini yang menyatakan bahwa preferensi berpengaruh positif dan signifikan terhadap keputusan pembelian pada D'besto di Kota Padang., dinyatakan diterima.

Hal ini bermakna preferensi akan memberikan pengaruh yang signifikan terhadap keputusan pembelian D'besto di Kota Padang, hal ini selaras dengan penelitian yang dilakukan oleh Widya Wardani (2015) tentang Pengaruh Persepsi dan Preferensi Konsumen Terhadap Keputusan Pembelian Hunian Green Products, menemukan bahwa persepsi dan preferensi berpengaruh signifikan terhadap keputusan pembelian. Sesuai dengan penelitian yang dilakukan oleh Immarotul Azizah (2008) tentang Analisis Pengaruh Persepsi dan Preferensi Konsumen terhadap Keputusan Pembelian, menemukan bahwa persepsi dan preferensi berpengaruh signifikan terhadap keputusan pembelian.

Berdasarkan hasil penelitian penulis bahwa penelitian terdahulu, dan penelitian sekarang sesuai dengan praktek lapangan yang di lakukan. Hal ini menyatakan bahwa pelanggan memiliki respon yang baik terhadap produk d'besto.

\section{SIMPULAN}

Berdasarkan analisis dan pembahasan hasil dikemukakan beberapa kesimpulan sebagai berikut:

1. Variabel Persepsi berpengaruh positif dan signifikan terhadap keputusan pembelian pada D'besto cabang Siteba.

2. Variabel Preferensi Konsumen berpengaruh positif dan signifikan terhadap keputusan pembelian pada D'besto cabang Siteba.

3. Pada pengujian tabel $F$ diperoleh bahwa Persepsi dan Preferensi berpengaruh signifikan secara simultan/bersama-sama terhadap keputusan pembelian pada D'besto cabang Siteba. 


\section{UCAPAN TERIMAKASIH}

Dengan selesainya penulisan artikel ini, penulis mengucapkan terima kasih kepada pihak-pihak yang membantu selama proses penulisan.

1. Bapak Febryandhie Ananda, SE, M.Si, selaku Ketua di STIE "KBP” Padang.

2. Ibu Lidya Martha, SE, MM selaku Wakil Ketua di STIE "KBP” Padang.

3. Ibu Febsri Susanti, SEI, MM selaku Ketua Program Studi Manajemen di STIE "KBP” Padang.

4. Ibu Maria Magdalena, S.Pd, MM, selaku Penasehat Akademik Program Studi Manajemen di STIE "KBP" Padang.

5. Ibu Riri Mayliza, SE, MM, selaku Pembimbing Proposal Skripsi di STIE "KBP” Padang

\section{DAFTAR PUSTAKA}

Adiningsih, Dyahnita. 2012. "Pengaruh Persepsi Siswa Tentang Metode Mengajar Guru Dan Kemandirian Belajar Terhadap Prestasi Belajar Akuntansi Siswa Kelas X Program Keahlian Akuntansi.”

Andika, A., \& Susanti, F. (2018). Pengaruh Marketing Mix Terhadap Keputusan Pembelian Parfum di Azzwars Parfum Lubeg Padang. https://doi.org/10.31227/osf.io/upgc3

Anggasari, Popy. 2013. "Pengaruh Ethnosentrisme Terhadap Sikap, Preferensi Dan Perilaku Pembelian Buah Lokal Dan Impor." Jurnal Manajemen \& Agri bisnis, Vol.10 No.2, Juli 2013 10(2): 128-36.

Astuti, Tri 2013. 2013. "Pengaruh Persepsi Nasabah Tentang Tingkat Suku Bunga, Promosi Dan Kualitas Pelayanan Terhadap Minat Menabung Nasabah.” II: 182-98.

Aziz, N. (2019). Pengaruh Strategi Promosi Terhadap Keputusan Pembelian Yang Dimediasi Oleh Minat Beli Pada Konsumen Restoran KFC Cabang Khatib Sulaiman Padang. https://doi.org/10.17605/OSF.IO/V92TS

Aziz, N. (2019). Analisis Pengaruh Kualitas Produk, Harga, Promosi Terhadap Keputusan Pembelian Air Minum Dalam Kemasan (AMDK) Merek Aicos Produksi Pt. Bumi Sarimas Indonesia. https://doi.org/10.17605/OSF.IO/8XKYB

Azizah, Imarotul. 2008. "Analisis Pengaruh Persepsi Dan Preferensi Konsumen Terhadap Keputusan Pembelian Buah Lokal."

Basril, Afrian. 2008. "Analisis Pengaruh Persepsi Dan Preferensi Konsumen Terhadap Keputusan Pembelian Merek." 
F., \& Afriyeni, A. (2019). Aktivitas Pemasaran Produk Tabungan Pada PT. Bank Pembangunan Daerah (BPD) Sumatera Barat Cabang Utama Padang. https://doi.org/10.31219/osf.io/tf2bz

F., \& Susanti, F. (2019). Pengaruh Faktor Psikografis Terhadap Keputusan Pembelian Sepatu Merek Mollinic Di PT. Ramayana Lestari Sentosa, Tbk Padang. https://doi.org/10.31227/osf.io/26ftz

Ghozali, Imam. 2011. “Aplikasi Analisis Multivariate Dengan Program IBM SPSS 20." In Book, Semarang: Badan Penerbit Universitas Diponegoro, 1298.

Hariadi, Doni. 2013. "Pengaruh Produk, Harga, Promosi Dan Distribusi Terhadap Keputusan Pembelian Konsumen Pada Produk Projector Microvision.” 1(8): $67-87$.

Jamarnis, S., \& Susanti, F. (2019). Pengaruh Harga Dan Periklanan Melalui Internet Terhadap Keputusan Pembelian Produk Sabun Merek Lux Pada Mahasiswa STIE “KBP” Padang. https://doi.org/10.31227/osf.io/xz3d8

Kurniawan, R., \& Susanti, F. (2019). Pengaruh Lifestyle Terhadap Keputusan Pembelian Pada Sepatu Merek Fladeo Di Basko Grand Mall Padang. https://doi.org/10.31227/osf.io/ehyau

Marlius, D. (2017). Keputusan Pembelian Berdasarkan Faktor Psikologis Dan Bauran Pemasaran Pada PT. Intercom Mobilindo Padang. Jurnal Pundi. Volume 1. No. 1. Hal. 57-66. https://doi.org/10.31575/jp.v1i1.9

Marlius, D. (2016). Pengaruh Bauran Pemasaran Jasa Terhadap Minat Nasabah Dalam Menabung Pada Bank Nagari Cabang Muaralabuh. https://doi.org/10.31227/osf.io/vdqgx

Sugiyono. 2015. Book Statistik Nonparametris Untuk Penelitian. Bandung: CV. Alvabeta.

Susanti, F., \& Gunawan, A. C. (2019). Pengaruh Bauran Promosi Dan Harga Terhadap Keputusan Pembelian Produk Kosmetik Maybelline Di Kota Padang. https://doi.org/10.31227/osf.io/npjqh

Wahyuni, Dewi. 2008. "Pengaruh Motivasi, Persepsi Dan Sikap Konsumen Terhadap Keputusan Pembelian Sepeda Motor Merek 'Honda' Di Kawasan Surabaya Barat." Jurnal Manajemen dan Kewirausahaan 10: pp.30-37. http://puslit2.petra.ac.id/ejournal/index.php/man/article/view/16790.

Wardhani, Widya. 2013. "Pengaruh Persepsi Dan Preferensi Konsumen Terhadap Keputusan Pembelian Hunian Green Product.” Journal of Management 6. 